\title{
THE EXPERIENCE OF SOCIAL PEDAGOGUES AND SOCIAL WORKERS WHEN PROMOTING POSITIVE BEHAVIOUR IN CHILDREN AT DAY-CARE CENTRES
}

\author{
Rita Raudeliūnaitè \\ Mykolas Romeris University, Lithuania
}

\begin{abstract}
The article presents the study, the purpose of which is to reveal the experience of social pedagogues and social workers when promoting positive behaviour in children at daycare centres. The qualitative type of research was chosen when applying the method of semistructured inteview. The data of the study were processed by applying the method of data content analysis. 3 social pedagogues and 5 social workers, who work at children day-care centres, participated in the study. The data of the study revealed that when promoting positive behaviour in children at day-care centres social pedagogues and social workers create positive relationships with children and strengthen positive interrelationships between children, have individual conversations with children. Meaningful use of children's leisure time plays an important role when promoting positive behaviour in children. In this case, it is important that the activities, which are organised for children, would be personally and socially meaningful, that they would encourage independence and responsibility in children and humane relationships. When promoting positive behaviour in children social pedagogues and social workers encourage the culture of teamwork and cooperation in order to maintain partnership relationships with parents of the child and other specialists by sharing their experience and rendering assistance to other.
\end{abstract}

Keywords: day-care centre, children, promoting positive behaviour, social pedagogues, social workers.

\section{Introduction}

The safeguarding of the child's welfare is a priority area in the national policymaking and its implementation. The Concept of the Child's Welfare of the Republic of Lithuania (2003) and The State Policy Strategy of the Child's Welfare (2005) define the child's welfare as facilitating conditions for the child to live a full life, the safeguarding of his right to protection, supply and participation in social life. These documents emphasise that the child should not experience poverty or social exclusion, the deprivation of realising their skills and helplessness when adapting to the changing conditions. The attention should be drawn to the fact that the measures of general scope, which seek the welfare 
of all children, should be coordinated with targeted measures aimed at the children, who are in the most disadvantaged social position. Therefore, when solving multiple problems, which children and their families face, various services should be developed. The development of services for children and families and investment into the improvement of their quality is a priority to the state.

The State Policy Strategy of the Child's Welfare (2005) points out that particular attention has to be paid to the children's day-care and education services when expanding the network of children's day-care centres. The main activity of children's day-care centres is the provision of socio-educational services (Targamadze, 2017). At children's day-care centres, socio-educational services are provided to children, who are at social risk, to children with disabilities and other children and their families (Catalogue of Social Services, 2006). The socio-educational activity is aimed at the full development of personal abilities, the creation of conditions for personal development and individual education, while ensuring personal full-blown socialization in his environment and social inclusion (Šereivienė \& Žydžiūnaitè, 2005).

It should be noted that a significant proportion of children, who attend daycare centres, are from families with negative conditions for children's development. Prevalent negative conditions in the family might lead to the formation of a socially immature personality, who is characterised by a negative worldview, inability to adapt to his environment, lack of self-esteem and selfcontrol, as well as antisocial behaviour. The strengthening of positive socialisation and the development of positive behaviour are of special relevance to children growing up in the families, in which negative conditions for children's development prevail. I. Liepinskaitė \& R. Motiečienė (2017) underline that child's day-care centres, which provide socio-educational services, contribute to the strengthening of positive socialisation in children.

Children's day-care centres provide a complex assistance, the purpose of which is to organise appropriate leisure activities for children after their lessons, to create a safe environment for them, detract from their negative social environment and to protect against an inappropriate behaviour, as well as to develop resilience to social risk factors in children, to promote and maintain their motivation in education, to assist them in feeling a full participant of social life and to increase their self-esteem (Masiliauskienè \& Griškutè, 2010). Daycare centres provide socio-educational assistance to a child's family in order to strengthen family's functioning, their empowerment and parental ability to nurture their child.

The first Lithuanian day-care centre was established in 1996, however, there is still lack of scientific research in this area. Day-care centres were researched in connection with management: their functions and management 
characteristics, territorial jurisdiction, interinstitutional collaboration and the assessment of their activity (Sipovič, 2007; Buzaitytė - Kašalynienè \& Liaudginaitė - Zamalienė, 2012). Certain studies analyse socio-educational assistance to families at social risk and their children (Favourable Environment for Children and Youth: Challenges and Opportunities, 2013), as well as the significance of the assistance rendered at day-care centres on the basis of children's experience (Indrašienė \& Šlapelienè, 2007; Masiliauskienė \& Griškutè, 2010) and opportunities to develop social skills in children at children's day-care centres (Jančiauskytè, Širiakovienè, \& Plaušinaitienè, 2013; Vaitiekienè, 2013; Gudžinskienè, Burvytė, \& Barkauskaitė, 2017). They also studied the implementation of children's rights at day-care centres (Gudžinskienè, Raudeliūnaite, \& Uscila, 2016). However, there is still lack of scientific research analysing the experience of employees, who work at day-care centres. It should be noted that The Study of the Activity of Children's Day-care Centres and the Assessment of Services Provided There and the Development of Their Opportunities (2015) underlines that, at day-care centres, it is very important to develop positive behaviour in children, to assess the effectiveness of socio-educational services in order to enhance positive socialisation in children by conducting both quantitative and qualitative studies.

The research aim was to reveal the experience of social workers and social pedagogues when promoting positive behaviour in children at day-care centres.

\section{Research Methodology}

Research methods. Qualitative research was chosen for the study. "Qualitative research is an approach for exploring and understanding the meaning individuals or groups ascribe to a social or human problem. The process of research involves emerging questions and procedures, data typically collected in the participant's setting, data analysis inductively building from particulars to general themes, and the researcher making interpretations of the meaning of the data" (Creswell, 2014, p.32). The data of the study was collected by using semi-structured interview in order to answer the following questions: how social pedagogues and social workers develop positive behaviour in children at day-care centres and what helps them to ensure the development of a positive behaviour in children at day-care centres. The data of the study was collected in the June-July of 2020.

The data of the study was processed by using a content analysis method. Qualitative analysis is a process of reviewing, synthesizing and interpreting data to describe and explain the phenomena being studied (Craswell, 2014). Qualitative content analysis was carried out in accordance with inductive, databased research, in which categories are logically assigned. The study content 
analysis was performed by taking the following steps: the reading of the transcribed interview texts for a few times; the coding of the study data; the grouping of codes, the creation of categories; the comparison of categories in between while distinguishing contrasts, underscoring the characteristics of each category and explaining the differences of categories; the creation of finite structure of categories on the basis of their interrelations and hierachy; the description of the study results and interpretation (Craswell, 2014). The participants of the study were asked to confirm the content of the categories and to provide additional commentaries, if they noticed any changes. The participants of the study did not change anything.

Research sample. Purposeful sampling was used. Selection criteria for research participants: the participants of the study were social workers and social pedagogues working at children's day-care centres whose experience of work with children at day-care centres is at least 3 years. 3 social pedagogues and 5 social workers, who work at children day- care centres, participated in the study.

Research ethics. The study was based on the respect for personal privacy, benevolence and attitude not to harm a researchee, confidentiality and anonymity (British Educational Research Association [BERA], 2018). The participants of the study participated voluntarily. They were briefed on the purpose and the use of the study, the method of study data collection and the procedure of the study, anonymity and confidentiality were ensured. Study participants were assigned a code by using the letter 'I' and a number (I1, I2 and so on).

\section{Analysis of Research Results}

The study took interest in how social pedagogues and social workers develop positive behaviour in children at day-care centres and what helps them to ensure the development of positive behaviour in children at day-care centres. Having analysed the study data, it was identified that social pedagogues and social workers while developing positive behaviour in children at day-care centres create a positive emotional environment, organise meaningful leisure for children and nurture the culture of teamwork.

The creation of a favourable emotional environment while developing positive behaviour in children. The study data shows that the creation of a favourable emotional environment at day-care centres should be associated with the creation of positive relationships between the employees and children, the enhancement of positive interrelationships between children and individual conversations with children (Table 1). 
SOCIETY. INTEGRATION. EDUCATION

Proceedings of the International Scientific Conference. Volume III, May $28^{\text {th }}-29^{\text {th }}, 2021.386-401$

Table 1 The Creation of a Favourable Emotional Environment while Developing Positive Behaviour in Children

\begin{tabular}{|c|c|}
\hline Category & Subcategory \\
\hline \multirow{3}{*}{$\begin{array}{l}\text { Positive relationships } \\
\text { of a social pedagogue } \\
\text { and social worker with } \\
\text { children }\end{array}$} & $\begin{array}{l}\text { Positive attitudes of a social pedagogue and social worker towards } \\
\text { all children }\end{array}$ \\
\hline & $\begin{array}{l}\text { The example of a social pedagogue's and social worker's positive } \\
\text { behaviour }\end{array}$ \\
\hline & $\begin{array}{l}\text { Relationships with children based on humanist values: respect, } \\
\text { self-confidence and assistance }\end{array}$ \\
\hline \multirow{2}{*}{$\begin{array}{l}\text { The enhancement of } \\
\text { positive relationships } \\
\text { between children }\end{array}$} & The promotion of positive interaction \\
\hline & The promotion of cooperation \\
\hline \multirow{4}{*}{$\begin{array}{l}\text { Individual } \\
\text { conversations with } \\
\text { children }\end{array}$} & Assist in knowing a child better \\
\hline & Assist in developing closer ties with a child \\
\hline & $\begin{array}{l}\text { Assist in choosing appropriate strategies of positive behaviour } \\
\text { development suitable to individual needs of a child }\end{array}$ \\
\hline & $\begin{array}{l}\text { Motivate and assist a child in changing his inappropriate } \\
\text { behaviour }\end{array}$ \\
\hline
\end{tabular}

Positive attitudes of the employees towards all the children are an important factor when creating positive relationships with children. According to the informants, "every child must matter and should feel welcome at the daycare centre, he needs to get the feeling of a warm, respectful communication with him" (14), "good relationships with children are possible when they feel accepted, feel that employees believe in them, when you don't downgrade, don't underestimate them" (15), "it is important to me to accept all the children such as they are and to think about a child positively, then, a desire arises to be with him, to help him to overcome arising difficulties, my own self-confidence, that I can do it, arises" (13).

The study shows that, when creating positive relationships with children, it is important that an employee would demonstrate an example of positive behaviour. According to the study participants, "if you start communicating with all the children respectfully, the children also notice it, this is exactly that example of the promotion of positive behaviour" (I7), "if we want to develop positive behaviour in children, let's act positively themselves, because children are very sensitive to that, and they adopt the examples of our behaviour" (I6), "children learn from us, we are their role models themselves" (I1).

The participants of the research emphasised that, when developing positive behaviour in children, it is important to base interrelationships on humanist values, especially politeness, attentiveness, confidence in a child, sincerity and assistance. The informants pointed out that "in order to achieve good behaviour in children you need to communicate with children pleasantly, warmly and very 
sincerely, to be interested in them, to ask them how they are doing, to show that they matters to us, that we want to help them when they need our help" (I8), "attention, confidence in a child, talking about child's needs, desires, experiences assists in starting and maintaining good interrelationships, which are very important when developing appropriate behaviour in children" (I3).

Similar tendencies were also revealed by other studies (Patrick, Ryan, \& Kaplan, 2007) which demonstrate that, in a great measure, the development of positive behaviour in children depends on the educator: his tactful, calm behaviour, his efforts to dispel fears, the manifestations of anxiety or tension. Therefore, it is important that an employee would display respect, friendliness, confidence in his strength, patience, if he fails, that he would also watch and control his own behaviour. According to S. Burvyte (2017), in order to lay foundations for the positive changes in child's behaviour, an educator must strike up a strong, friendly relationship with a child based on mutual trust. Only when a relationship, which is based on trust and understanding, emerges the person is able to obtain more confidence in his strength, to draw the appropriate conclusions regarding their behaviour and muster courage to make changes.

The study data revealed that social pedagogues and social workers, when developing positive behaviour in children, aim at strengthening positive relationships between children by encouraging children to learn to communicate and cooperate properly. The study participants pointed out that "the communication of a significant part of children is impaired, therefore, a lot of attention needs to be paid in order that children would learn to communicate properly" (I2), "children have a great lack of communication skills, therefore, we teach these skills in their daily communication, we devote special activities for that" (I8); "children are taught communication, communication culture in various daily situations and the activities that we organise" (I1); "we are creating a communicating community, because the child can learn appropriate mutual relationships and cooperate only in such community" (I4). According to N.Sturliene (2005), when there is tension in the group due to insecurity, distrust towards one another, where everybody takes care only of himself, when there are small groups, within in the group, which don't see eye to eye, children feel one way. It is a completely another matter when the group lives in unity, when everyone feels being a part of it, accepted and important. According to B.Bitinas (2004), while being in a cooperating community, the child perceives himself as a full member of his community, experiences the feeling of security, is not afraid that he can be hurt or disdained, he learns to analyse and assess himself, understands his both belonging to the community and individuality, acquires the experience of communication and cooperation.

The study revealed that when developing positive behaviour in children employees hold individual conversations with children. It is conveyed by the 
following statements made by the informants: "when developing proper behaviour in a child an individual conversation with the child is unavoidable, it is very important, it must be dominated by sincerity and avoidance to condemn the child, it must be dominated by the desire to understand him and help him" (I2), "during conversations, first of all, I try to learn about a child's situation, and, only having known the child, his behavioural or other problems, it is possible to foresee what kind of assistance he needs, how to help him" (I3), "during conversations with the child, we seek to find out the strengths of the child, as well as difficulties arising to him. We talk, discuss, we look for solutions to arising difficulties" (I7), "there are very different approaches to every child, therefore, while developing positive behaviour I endeavour to take into consideration a child's situation, his needs" (I8), "when a child lacks resolution, for example, to change his inappropriate behaviour then, while talking with him, I try to motivate him that he would make a decision himself, that he would take steps towards his change, and I try to support him, to discuss his progress, to help him on his way towards changes" (I4). The study data demonstrates that, during individual conversations, employees endeavour to get to know the child better, to choose appropriate strategies to develop positive behaviour which are suitable to child's needs. They also motivate and assist the child in changing his inappropriate behaviour. It should be noted that, during individual conversations, employees seek to establish and maintain close relationships, which are based on mutual trust, with children. When there is positive reciprocal interaction children become not so reserved, they exhibit a greater measure of cooperation with employees when resolving their difficulties and developing positive behaviour. In addition, not only does an educator need to communicate sincerely with the child, but he also needs to endeavour not to condemn him because of his inappropriate behaviour, to try to elucidate the causes of such behaviour, which encouraged them to act in such manner, and to show that there is a supportive man, who wants to assist him in finding out solutions to problems (Rupšienė, 2004). According to S. Burvyte (2017), a positive educational conversation is an effective tool enabling to change a destructive model of the child's behaviour into a positive one.

Meaningful children's leisure activities. The study revealed that positive behaviour in children is developed by organising various leisure activities. These activities influence child's behaviour in a positive manner when the child perceives them as personally and socially meaningful, when they encourage and develop his independence and responsibility, whereas strategies, which are applied to manage children's behaviour, assist in strengthening socially appropriate behaviour (Table 2). 
Raudeliūnaitè, 2021. The Experience of Social Pedagogues and Social Workers when Promoting Positive Behaviour in Children at Day-Care Centres

Table 2 The Development of Positive Behaviour in Children by Organising Leisure Activities

\begin{tabular}{|c|c|}
\hline Category & Subcategory \\
\hline \multirow{4}{*}{$\begin{array}{l}\text { Personal } \\
\text { Meaningfulness of } \\
\text { Activities to the Child }\end{array}$} & $\begin{array}{l}\text { Activity which conforms to the interests, inclinations and } \\
\text { preferences of child }\end{array}$ \\
\hline & Activity encouraging child's self-expression \\
\hline & Social skills of the child are developed \\
\hline & Involvement in it results in success and pleasant experiences \\
\hline \multirow{2}{*}{$\begin{array}{l}\text { Social } \\
\text { Meaningfulness of } \\
\text { Activities to the Child }\end{array}$} & Perform different social roles \\
\hline & Carry out good works to others \\
\hline \multirow{3}{*}{$\begin{array}{l}\text { Encouragement of } \\
\text { Independence and } \\
\text { Responsibility in } \\
\text { Activity }\end{array}$} & To encourage children to perform various tasks independently \\
\hline & $\begin{array}{l}\text { To assist in understanding that the success of an activity depends } \\
\text { on his effort }\end{array}$ \\
\hline & To form a habit to perform assumed tasks carefully \\
\hline \multirow{4}{*}{$\begin{array}{l}\text { Management of } \\
\text { Children's Behaviour } \\
\text { while Promoting } \\
\text { Socially Acceptable } \\
\text { Behaviour }\end{array}$} & Positive behaviour of the child is strengthened and supported \\
\hline & $\begin{array}{l}\text { To teach the child to encourage himself and others for good } \\
\text { behaviour and work }\end{array}$ \\
\hline & Creation of behaviour rules and compliance with them \\
\hline & $\begin{array}{l}\text { To react to inappropriate behaviour of the child thoughtfully and } \\
\text { properly }\end{array}$ \\
\hline
\end{tabular}

In terms of educological aspect, the criterion of the meaningfulness of an activity to the child is important, because changes in the personality and behaviour of the child are positive only then, when he believes in the meaningfulness and value of what he does (Bitinas, 2004). According to the informant, "purposeful and meaningful engagement is very important to children, because otherwise children most often start behaving inappropriately due to boredom or not knowing what to do with themselves" (I6). The data of the study demonstrates that when developing positive behaviour in children it is important that an activity would be personally meaningful. On the basis of the study data, an activity will be personally meaningful when it will conform to interests, inclinations and preferences, when the child will be able to express himself, will experience success and will develop social skills. The participants of the study pointed out that, by involving children in various activities, they seek to take into consideration individual abilities, needs, interests and preferences of the child and create opportunities for the child to express himself. It is conveyed by the following statements of the informants: "an activity is selected according to their abilities and preferences, it is necessary that it would be liked by the child, then, he gets involved in it, it becomes acceptable to him and effective" (I2), "children are very creative, curious, they want to express themselves, therefore, we devote much attention to their self-expression, we encourage them to try themselves in various activities, to discover what is 
interesting to them" (I3), "when a child can express himself, reveal himself, show his abilities all of that boosts self-confidence of children, strengthens their confidence in their abilities, they begin behaving in a more responsible manner" (I6), "I encourage children to express their opinion, to tell what kind of events they would like, I involve them in the organising of activities in order that everyone would contribute according to his abilities, would not remain unnoticed, uninvolved, this is how the 'I can" feeling of the child and responsibility are boosted" (I1).

The participants of the study pointed out that the social skills in children are developed by organising different leisure activities at day-care centres. The impact of activities on children's social skills is determined by the measure in which they enrich social relationships of the children and assist in forming socially appropriate behaviour. The informants emphasised that various activities are aimed at creating positive interrelationships while children learn to behave politely, to communicate respectfully, to resolve disagreements properly, to trust each other, not to disdain each other, to listen to each other, to apologise, if somebody is not right and the like. The informants also pointed out that when developing social skills in children they use different methods: "most often we have team exercises by involving in various educational games, as well as different films are watched, after that, we talk them over, we hold various discussions. We talk about what children think, what that man felt in that situation, what he would feel in such situation, we discus what could have influenced one or another behaviour, we discuss various situations arising at the centre as well" (I3), "during social skills lessons, we analyse, model and learn to behave nicely" (I8). Similar tendencies were also revealed by other studies which demonstrate that children's day-care centres, which develop social skills in children through various socio-educational activities, assist in resolving different problems in children related to their inappropriate behaviour (Gudžinskienè et al., 2016). According to Pihlaja, Sarlin, \& Ristkari (2015), problematic behaviour in children is often related to the lack of social skills.

The study data revealed that when developing positive behaviour in children it is important that while performing activities the child would experience positive feelings and success. In order to achieve that it is important, according to the participants of the study, "to set clear and achievable goals, then, he achieves them, starts trusting himself more, becomes more motivated" (I7), "to assign tasks according to child's abilities in order that he would be able to perform them, would experience success, if need be, he gets help, to praise the child for his effort, performed work, this is how the child starts trusting himself more and more, he becomes more active, his behaviour improves" (I4). According to the participants of the study, "when an activity is not interesting to a child, it is too complicated, and the child experiences failures, he is angry, he 
gets disappointed, gets indifferent," "we cannot hope to benefit from any activity into which the child gets involved unwillingly, as if he is forced, when he is not interested in it, therefore, I endeavour that an activity would give good emotions, he would participate in it willingly, would grow in it" (I6).

The study revealed that when developing positive behaviour in children it is important that activities would be socially meaningful to the child, assisting in acquiring useful social experience. The participants of the study pointed out that a socially useful activity is diverse, encompassing activity at the day-care centre and outside of it. According to the statements made by the informants, obligations imposed on children and obligation assumed by them at the day-care centre acquire particular importance. They allow the child to perform various social roles, to improve communication and cooperation skills, to get the feeling of being an important member of the centre community: "children have various obligations imposed on them and obligations assumed by them at the day-care centre, these are elected posts, various imposed or assumed tasks, duties when organising various activities or performing works, this is how children learn to be responsible, to make decisions and to develop independence" (I1), "in various activities, I encourage children to cooperate: to consult each other, to share tasks, to help each other, to communicate nicely and the like" (I2), "while performing activities children perform various roles: they plan, organise, help, lead. I endeavour that children would try themselves in different roles and would try themselves in new roles, if somebody is not so bold or doubts, I encourage him. I also encourage that children themselves would cheer up each other, would support, would help each other... Through various roles, they also acquire more diverse social experience and learn to behave appropriately" (I3).

The participants of the study pointed out that children participate in different organised social events, projects, do good works. According to the informants, "this activity assists children in expanding the scope of their social relationships, to form socially appropriate behaviour" (I7), "children, when doing good works to others, start feeling significant, develop self-confidence" (I1), "the benefits of such activity are great, I can often see joy experienced by children, their pride in themselves, because they can contribute something..." (I5). According to I. Klanienè \& G. Šmitienè (2013), children, who get involved in social activities, are able to know better the needs of other people, to learn to meet them, to feel satisfaction and pride in their activity. Children also develop moral values: respect, tolerance, dutifulness, responsibility and citizenship.

The study data shows that when developing positive behaviour in children it is of relevance to encourage independence and responsibility in children through different activities. The participants of the study maintained that they assign various - both individual and directed at small groups - independent tasks, during which children learn to set goals, to plan, to assess, to choose tools and 
methods. An employee mostly undertakes the role of the assistant. The informants notice that children perform tasks more willingly when they have an opportunity to choose, to present their suggestions, to put in their understanding and creativity.

On the other hand, according to the informants, it is equally important to assist children in understanding that there is a close link between the amount of their effort, which is put in, and success. According to the informant, "some children give up quickly when they encounter some kind of a difficulty and want that somebody else would do something in their stead, then, I encourage that they would firstly look for solutions and would engage somebody else as an assistant while searching for solutions, but not as a solution provider" (I5), "when a child experiences a failure I attempt to elucidate what he has been doing and what he is going to do; very often they say 'I don't know,' then, I help them not by giving a direct answer, but by asking questions, which encourage them to make efforts themselves and to find out the answer or solution, I praise for efforts. I only accompany, but I don't try to do it in child's stead, and I encourage others to stick to such strategy" (I2). The informants also pointed out that they motivate children to perform tasks and works assumed by them carefully. In this way the child's responsibility, self-confidence and self-control are developed. Thus, the ability of the educator to express his faith in the ability of the child to overcome difficulties (to instill hope in the child by encouraging him, supporting him, praising him for his efforts) should be deemed as a significant condition to develop positive behaviour.

The study revealed that, at day-care centres, social pedagogues and social workers, when developing positive behaviour, apply various strategies, which encourage socially acceptable behaviour, to manage children's behaviour. One of them is the reinforcement and maintenance of positive behavior. The study revealed that it is important to notice appropriate behaviour exhibited by the child: "these are praises that we use to encourage positive behaviour, we pay attention to child's positive behaviour when the child behaves nicely, does something good, you praise for behavioural changes achieved by them or improved learning outcomes, he is joyful, he is smiling, he is happy, he wants to behave nicely" (I7).

On the other hand, according to the informant, "we always try to react to any problematic behavioural act, we don't leave it unnoticed, we don't pretend that nothing happened. We stop and don't allow it to gain momentum, we clarify it immediately, we talk with the child and look for possible solutions together, it's not about how great punishment is, but that the child would understand the consequences of his inappropriate behaviour and would be willing to change his behaviour... when we see that the child tries to change his behaviour we support and praise him" (I6). R.K. Wheatley et al. (2009) also note that in particular 
children are motivated to change when their appropriate behaviour is noticed. Praising and thanking are very important to the child, because they motivate children to improve and encourage the establishment of appropriate behaviour (Wheatley et al., 2009).

The results of the study show that the participants of the study, when developing positive behaviour in children, teach the child to praise himself and others for good behaviour, work, efforts and achievements: "it is important to me not only to praise a child, but also to teach the child to praise himself, to notice his own strengths, to rejoice in his own good act or work. I often ask the child how he feels after helping another person, having behaved nicely or the like. In such a way, he learns, gradually, to notice and to rejoice in his own good deeds himself" (I4), "it should be observed that children, when assessing each other's work, first of all, begin by expressing disdainful criticism, so I teach that, first of all, they need to start noticing positive, good things, whereas observations should be presented politely, without underestimating and humiliating others" (I1), "I teach to pay compliments to each other, to rejoice in each other" (I3).

Another method, which is applied to develop positive behaviour, is the creation of behaviour rules and compliance with them. This is corroborated by the following statements made by the informants: "we create the rules of good behaviour together with children, then, they comply with them willingly and learn to behave appropriately" (I1), "we don't present rules to the children, but we write down behaviour rules, which apply to all, together, and oblige themselves to stick to them" (I8), "we create rules, which help create good interrelationships, together with children, for example, to listen to each other, to talk politely, not to mock others and the like. We supplement them, if we see that it is necessary to add some rule" (I5). It demonstrates that employees create communication rules, which assist in creating friendly relationships with others, together with children. When creating rules it is important to cooperate with children, thereby the child will not feel that the adults forced unacceptable rules on him.

The study results show that the employees try to react to inappropriate behaviour of the child thoughtfully and appropriately: "it doesn't matter how difficult it is, firstly, I say 'stop' to myself, then, I think over and talk with the child calmly" (I5), "I try to react calmly, and I feel that when you react calmly they calm down as well" (I8), "it's necessary to try to react calmly, not to loose your temper, to talk with the child calmly, respectfully" (I1). It shows that in order to help the child it is necessary that the reactions of the adults would be thoughtful and appropriate. Spontaneous reactions towards problematic behaviour of the child may only worsen the situation. Furthermore, children learn from the emotion management strategy employed by the adults. 
Teamwork. The study revealed that when developing positive behaviour social pedagogues and social workers nurture teamwork culture, which is based on the cooperation with the parents of the child and other specialist (Fig. 1).

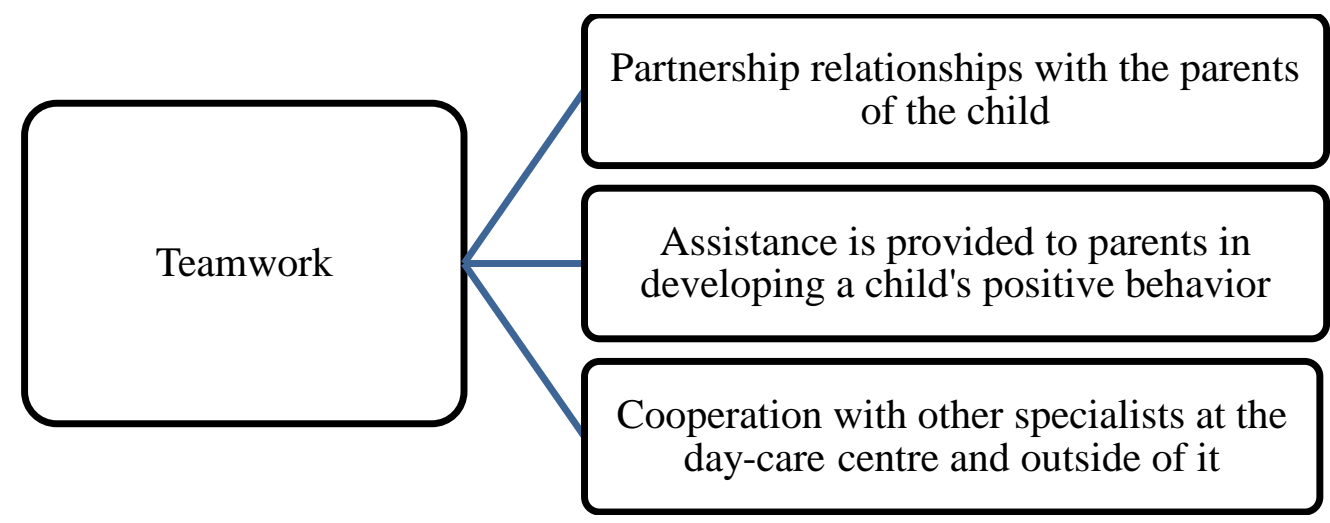

Figure 1 Teamwork in Developing Children's Positive Behaviour

The data of the study shows that the informants, who participated in the study, while cooperating with the parents of the child use empowerment approach by creating mutual partnership relationships and involving them in the making and implementation of decisions, which are related to their child, this in turn assists the child's parents in feeling competent to develop their child. The informants pointed out that they aim at maintaining close ties with the parents of the child: "we talk a lot with parents individually, we consult with them...cooperation assists us in knowing the child better, his situation in his immediate environment and meeting individual needs of the child...we involve parents in various events" (I2), "when developing positive behaviour of the child we discuss with his parents what strategies we will follow and foresee everyone's responsibilities and obligations" (I6). The informants pointed out that there are numerous instances when parents are focused on behavioural problems of their child without seeing and failing to overcome obstacles in their home environment. Employing teamwork enables them to perceive arising problems in a wider context. According to one of the informants, "talking and acting together help expand the vision of the behavioural problems of the child, discuss thoroughly and see what needs to be changed at home, where to direct attention at the centre when developing positive behaviour of the child" (I3).

The participants of the study pointed out that they organise training courses for parents on topical issues by engaging the specialists of the centre and those of other institutions in order to assist in solving problems related to the behaviour of the child or other educational difficulties. Social pedagogues and social workers, as well as psychologists consult parents on the topics of relevance to them. If they are not able to render assistance at the centre, they inform parents who can render assistance to them, if need be, they mediate by 
assisting in obtaining necessary help. Some centres organise the courses of the development of parental skills for parents.

The informants maintained that they cooperate with the specialists of their centre and those of other institutions not only while rendering assistance to the child and his parents, but they also exchange good practice when developing positive behaviour in children. The participants of the study underlined that they take different courses to improve their professional competence, which in turn assist them in developing positive behaviour in children. The cooperation with other institutions is also of relevance when consultations are held and while receiving support and having encountered more complicated instances of the problematic behaviour of children.

\section{Conclusions}

The study revealed that when developing positive behaviour in children social pedagogues and social workers create a favourable emotional environment at day-care centres, organise meaningful leisure for children and nurture teamwork culture.

The study showed that when creating a favourable emotional environment it is important to establish and to maintain positive relationships between employees and children and to strengthen positive relationships between children, as well as to talk individually with the child. Positive attitudes towards all the children, their example of positive behaviour and the basing of relationships with children on humanist values facilitate the creation of positive relationships with children. The strengthening of positive relationships between children should be associated with the teaching of children to communicate and cooperate among themselves appropriately. Individual conversations with children empower the employee to know the child better, assist in establishing closer ties with him and choosing appropriate strategies, which conform to individual needs of the child, that develop positive behaviour, and motivating the child and helping him change his inappropriate behaviour.

The study established that the development of positive behaviour when organising leisure activities should be associated with the personal and social meaningfulness of activities to the child, the strengthening of independence and responsibility in their activity, and the management of child behaviour when encouraging socially acceptable behaviour. An activity will be meaningful to the child when it conforms to the interests, inclinations and preferences of the child, promotes the self-expression of the child, assist in developing social skills, and the child experiences success and pleasant feelings when performing it. An activity will be socially meaningful to the child when he performs various social roles and does good works to others. When developing positive behaviour in 
children it is also of relevance to develop independence and responsibility in children in various activities by encouraging children to perform various tasks while assisting in understanding that the success of an activity depends on efforts, which are put in, and accustoming them to perform assumed tasks and works carefully. The management of children's behaviour, while encouraging socially acceptable, also take on important connotations. In this case, it is important to strengthen and to support positive behaviour of the child, to teach the child to incentivize himself and others for good behaviour and work, to create behaviour rules together with children and comply with them, as well as to thoughtfully and appropriately react to inappropriate behaviour of the child.

The study revealed that when developing positive behaviour in children teamwork is important. On the one hand, it is important to cooperate with the parents of the child while creating and maintaining partnership relationships with them, involving them in the process of the development of positive behaviour in the child and its continuity at home, as well as organising assistance to them to develop positive behaviour. On the other hand, it is important to cooperate with other specialists both at the centre and outside of it when rendering assistance to the child, his parents, exchanging good practice, developing positive behaviour in the child, as well as getting consulted and receiving support and encountering more complicated instances of child's behaviour.

\section{References}

Bitinas, B. (2004). Hodegetika. Auklejimo teorija ir technologija. Vilnius: Kronta.

British Educational Research Association [BERA]. (2018). Ethical Guidelines for Educational Research, fourth edition, London. Retrieved from https://www.bera.ac.uk/ researchers-resources/publications/ethical-guidelines-for-educational-research-2018

Burvyte, S. (2017). Ugdytojų pozityvus edukacinis pokalbis kaip ikimokyklinio amžiaus vaikų harmoningo ugdymosi užtikrinimo sąlyga. Socialinis Ugdymas, 47(3), 6-23. doi: $10.15823 /$ su. 2017.18

Buzaitytè-Kašalynienė, J., \& Liaudginaitè-Zamalienè, E. (2012). Vaikų dienos centrų tarpdalykinio bendradarbiavimo patirtis. Socialine teorija, empirija, politika ir praktika, 6, 7-22. doi: 10.15388/STEPP.2012.0.1862.

Catalogue of Social Services. (2006). Retrieved from https://e-seimas.lrs.lt/portal/ legalAct/lt/TAD/TAIS.274453

Creswell, J.W. (2014). Research design: Qualitative, Quantitative and mixed methods approaches. London: Sage.

Gudžinskienė, V., Burvytė, S., \& Barkauskaitė, M. (2017). Vaikų dienos centrų specialistų patirtys ugdant vaikų socialinius ịūdžius. Pedagogika, 4, 128-146.

Gudžinskienè, V., Raudeliūnaitè, R., \& Uscila, R. (2016). Vaiko teisių igyvendinimo galimybės vaikų dienos centruose. Pedagogika, 121(1), 209-224.

Indrašienè, V., \& Šlapelienè, E. (2017). Vaikų požiūris ị jų lankomus vaikų dienos centrus. Socialinis ugdymas, 3(14), 19-29. 
Klanienè, I., \& Šmitienė, G. (2013). Mokinių prosocialaus elgesio skatinimas socialiai aktyvia veikla. Tiltai, 64(3), 141-152.

Liepinskaitè, I., \& Motiečienè, R. (2017). Igalinančios socialinès paslaugos vaikų dienos centruose: Socialinių darbuotojų perspektyva. Socialinis darbas. Patirtis ir metodai, 20(2), 29-53. DOI: 10.7220/2029-5820.20.2.2.

Masiliauskienė, E., \& Griškutè, V. (2010). Vaikų dienos centrų teikiamos pagalbos socialinès rizikos šeimų vaikams raiškos kontekstų empirinis tyrimas. Mokytojų ugdymas, 14(1), 138-155.

Favourable Environment for Children and Youth: Challenges and Opportunities. (2013). Retrieved from https://socmin.lrv.lt/uploads/socmin/documents/files/pdf/6114_2013palanki_aplinka_vaikams_ir_jaunimui.pdf

Patrick, H., Ryan, A., \& Kaplan, A. (2007). Early adolescents' perceptions of the classroom social environment, motivational beliefs, and engagement. Journal of Educational Psychology, 99, 83-98.

Pihlaja, P., Sarlin, T., \& Ristkari T. (2015). How Do Day-Care Personnel Describe Children with Challenging Behaviour? Education Inquiry, 6(4). DOI: 10.3402/edui.v6.26003.

Rupšienè, L. (2004). Individualus socialinių pedagogų darbas su vengiančiais lankyti mokyklą mokiniais. Pedagogika, 70, 175-180.

Sipovič, I. (2007). Vaikų dienos centrų administravimo ir vertinimo problematiškumas. Viešoji politika ir administravimas, 22, 85-95.

Šereivienè, A., \& Žydžiūnaitè, V. (2005). Socialinio darbuotojo kompetencijos komponentai socioedukacinio darbo kontekste. Sveikatos ir socialiniu mokslu taikomieji tyrimai: sandūra ir saveika, 1, 6-23.

Sturlienè, N. (2005). Moksleivių elgesio problemos ir jų sprendimas. In Unifikuotas mokyklos bendruomeniu psichosocialinio konsultavimo modelis, 13-22. Vilnius.

Targamadze, V. (2017). Socioedukacinis klasteris kaip vaikų dienos centro veiklos dekompozicijos galimybė: kūrimo diskursas. Socialinis ugdymas, 45 (1), 6-13 DOI: http://dx.doi.org/10.15823/su.2017.1

The Concept of the Child's Welfare of the Republic of Lithuania. (2003). Retrieved from https://e-seimas.lrs.lt/portal/legalAct/lt/TAD/TAIS.211767

The State Policy Strategy of the Child's Welfare. (2005). Retrieved from https://eseimas.lrs.lt/portal/legalAct/lt/TAD/TAIS.250552/asr

The Study of the Activity of Children's Day-care Centres and the Assessment of Services Provided There and the Development of Their Opportunities. (2015). Retrieved from http://www.socmin.lt/lt/tyrimai.html.

Vaitiekienè, N. (2013). Socialinès rizikos šeimų vaikų, lankančių dienos veiklos tarnybą, socialinių igūdžių analizè. Profesinès studijos: teorija ir praktika, 11, 124-135.

Wheatley, R.K., West, R.P., Charlton, C.T., Sanders, R.B., Smith, T.G., \& Taylor, M.J. (2009). Improving behavior through differential reinforcement: A praise note system for elementary school students. Education \& Treatment of Children, 32(4), 551-571. https://doi.org/10.1353/etc.0.0071 